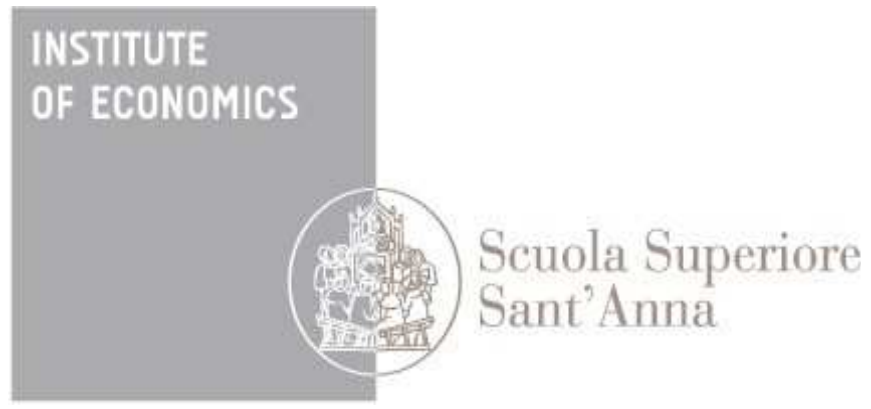

LEM | Laboratory of Economics and Management

Institute of Economics

Scuola Superiore Sant'Anna

Piazza Martiri della Libertà, 33 - 56127 Pisa, Italy ph. +3905088.33 .43$

institute.economics@sssup.it

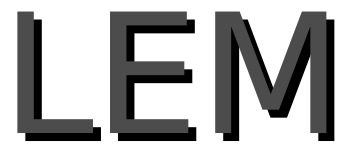

Working Paper Series

\title{
Real Estate and the Great Crisis: Lessons for Macro-Prudential Policy
}

\author{
John V. Duca ${ }^{\circ}$ \\ Lilit Popoyan* \\ Susan M. Wachter $\S$ \\ Research Department, Federal Reserve Bank of Dallas, and Southern \\ Methodist University, USA \\ * Institute of Economics, Scuola Superiore Sant'Anna, Pisa, Italy \\ $\S$ Wharton School, University of Pennsylvania, USA
}




\title{
Real Estate and the Great Crisis: Lessons for Macro-Prudential Policy*
}

\author{
John V. Duca ${ }^{\dagger} \quad$ Lilit Popoyan ${ }^{\ddagger} \quad$ Susan M. Wachter ${ }^{\S}$
}

\begin{abstract}
From a broad macro-financial structure perspective, overly easy credit conditions gave rise to house price booms and busts in several advanced economies (e.g., Ireland, Spain, and the U.S.), and, more specifically in the U.S., an underpricing of risk made possible by regulatory arbitrage and shadow financing fueled the credit and twin real estate bubbles of the mid2000s. Across countries and over time bubbles have been particularly acute in real estate markets reflecting not only the relatively inelastic supply of land and thin trading of real estate, but also the amplification of shocks via backward-looking price expectations and the funding of consumption off distorted and elevated prices. The macro-prudential lessons from the Great Crisis highlight the need to prevent the build-up of excess real estate financing and limit the amplification and correlation of real estate risks. And progress has been made in each of these areas through imposing tougher or new restrictions on the choice sets of lenders or of borrowers, with particulars varying across advanced economies. While regulatory reform of banking is going forward, significant challenges remain especially in dealing with correlated risks associated with securitization.
\end{abstract}

Keywords: Macro-prudential policy, financial crises, credit crunches, real estate bubbles, regulatory arbitrage, risk-taking

JEL classification numbers: G28, E3, R31, R33, R38

\footnotetext{
${ }^{*}$ We thank Michael Weiss and seminar participants at Oxford and the 2016 European Meetings of the International Finance and Banking Association (IFABs) for comments and suggestions. The views expressed are those of the authors and do not necessarily reflect those of the Federal Reserve Bank of Dallas or the Federal Reserve System. Lilit Popoyan gratefully acknowledges financial support from European Unions Horizon 2020 grant: No. 640772 - Project Dolfins. Any errors are our own.

${ }^{\dagger}$ Research Department, Federal Reserve Bank of Dallas and Southern Methodist University; E-mail address: john.v.duca@dal.frb.org.

${ }^{\ddagger}$ Institute of Economics (LEM), Scuola Superiore Sant’Anna, Pisa (Italy); E-mail address: lilitpopoyan@gmail.com.

${ }^{\S}$ Wharton School, University of Pennsylvania; E-mail address: wachter@wharton.upenn.edu
} 


\section{Introduction}

The consensus before the financial crisis of 2007-09 was that monetary policy should avoid curbing financial excesses if doing so conflicted with the central bank's goal of keeping inflation and/or unemployment near target. This view explicitly assumed that monetary policy lacked enough tools to pursue multiple targets and was too blunt to address financial stability-a view largely still intact. Implicit was a belief that Basel II made the financial system resilient enough to survive the unwinding of financial excesses, giving authorities sufficient time to conduct needed bailouts and for fiscal and monetary policy to clean up damage to the macro-economy and financial system. In addition, the pre-crisis consensus view also implicitly under-appreciated how much real estate imbalances could directly contribute to deep recessions and sluggish recoveries.

The 2007-09 financial crisis and recession shattered these implicit assumptions. By mid-2010 when Basel III was announced and when the Dodd-Frank (financial reform) Act ("DFA") was passed in the U.S. and the Capital Requirements Directive ("CRD IV") and Capital Requirement Regulation ("CRR") were announced by the EU, the emerging post-crisis consensus accepted that the financial system was neither resilient enough to survive large financial shocks nor could policy effectively clean up the macro-economic damage after crises occurred. Systemic risk to the financial system and real economy was seen as so prevalent, that new macro-prudential policies were needed to address these risks, allowing monetary policy and fiscal policy to focus on broad macroeconomic goals (e.g., Blanchard et al. 2010). Although both the theoretical and empirical framework of macro-prudential policy was still in its infancy-with limited guidance for policy-the U.S. and European countries, in the wake of the crisis, adopted measures to contain systemic risks associated with real estate. Given the practical challenges of reaching political consensus to pass such reforms in the proverbial heat of the moment, there was not enough time for either Basel III or DFA to be based on a full diagnosis of the financial crisis.

For example, in the U.S., DFA took a kitchen-sink approach of passing widespread guidelines aimed at curbing financial practices and factors that may have plausibly contributed to the crisis. The EU, instead, is digesting the regulatory requirements under the CRD IV and CRR that introduce harmonized prudential rules akin to the Basel III accord. And although much care and time was taken to write the rules to implement DFA's guidelines, it was difficult, if not impossible, for the many regulations to benefit from extensive research on the crisis, much of which had yet to appear in print. For example, small and midsize banks have complained about increases in regulatory burden that particularly disadvantage banks that operate at a smaller scale.

Nine years after the crisis, which began in summer 2007, the financial system continues working to implement Basel III financial reforms. And in the U.S., eight years after the government sponsored entities, Fannie Mae and Freddie Mac were put into conservatorship; reform of the housing finance system is still in discussion. Over this time, the post-crisis consensus has continued to evolve in at least two major ways. First, real estate busts are now seen as critically contributing to deep downturns and sluggish recoveries by impairing the financial system with losses and households with debt-overhangs. There is recognition that across countries and over time, bubbles arising in real estate markets can be acute, reflecting not only the relatively inelastic supply of land and thin trading of real estate, but also the amplification of shocks via 
backward-looking price expectations and the funding of consumption off distorted and elevated prices. Second, there is a growing appreciation for the need of macro-prudential policy to address externalities that cause build-ups of imbalances that lead to crises, directly amplify the effects of shocks during crises, and indirectly amplify these effects by creating correlated risks. More recently, there are widespread concerns about whether the long-term growth rates of U.S. and European GDP have slowed. Are these transitional effects from implementing financial reform (or residual effects of the unwinding of the crisis) that will eventually unwind or, alternatively, have financial reforms slowed the underlying dynamism of advanced economies?

Given the depth of the Great Recession and the sluggish recovery, it is appropriate to reassess the macro-prudential policy lessons learned, problems solved, and challenges remaining. We begin by reviewing the lessons that can be drawn from the experience surrounding the Great Recession, its aftermath, and what financial reforms have done. We then assess how macro-prudential policy could better address critical risks posed by real estate lending and raise questions about whether other regulations pose enough macro-prudential benefits to warrant the burdens imposed. In this endeavor, our approach focuses on the nature of key macroprudential externalities-particularly those posed by real estate-and how their manifestation in real estate valuation swings can be contained. In this way, macro-prudential policy can be better grounded-both theoretically and empirically-and hopefully, better implemented.

\section{Macro-Prudential Lessons Learned From the Great Recession}

There is a growing consensus that the bursting of real estate bubbles has contributed greatly to prolonged downturns (Bordo \& Haubrich 2012, Crowe et al. 2013) in being either the impulse for, (e.g., the Great Recession) or an amplifier of, them (e.g., the Great Depression, Green \& Wachter 2007). In some countries that experienced severe downturns, such as Ireland and Spain, the demand for real estate was bolstered not only by low mortgage interest rates, but also by an excessive easing of credit standards via either making too many loans with explicitly high LTVs (e.g., Ireland-see Kelly et al. 2015) or circumventing covered bond caps on the LTVs of mortgages by substituting inflated appraised prices for actual transactions prices (as in Spain) or by avoiding regulatory limits on banks by lending through less regulated depositories (e.g., cajas in Spain). ${ }^{1}$ The resulting high prices triggered building booms that later expanded supply during the house price bust that ultimately worsened loan losses and crippled financial systems.

Weak regulation took a different form in contributing to the housing bust and the Great Recession in the U.S., which can be interpreted as being triggered by the collapse of structured finance that had earlier spawned credit-fueled bubbles in residential and commercial real estate, the bursting of which ultimately crippled the U.S. financial system and its real economy (Duca et al. 2010, Levitin \& Wachter 2012). An overview of recent evidence on the Great Recession and shadow banking in the U.S. sheds light not only why real estate downturns are so severe and

\footnotetext{
${ }^{1}$ In other countries, higher house prices early in this century owed more to low interest rates fueling upward shifts in the demand for housing against a relatively price inelastic supply of housing (e.g., the Netherlands or France, see Duca et al. 2010). In others, real house prices were flat in the early 2000s reflecting factors such as declining population (e.g., Germany and Japan) or tax laws favoring rental housing (e.g., Germany).
} 
long-lasting, but also on the tendency for real estate mispricing to give rise to large swings in both residential and commercial real estate prices and valuations. In addition the U.S. experience shows how bubbles can arise from the shadow banking sector, an issue still not fully accounted for by financial reform, as discussed below.

\subsection{How and Why Real Estate is Vulnerable to Mispricing}

In the U.S., the residential and commercial ("twin") real estate booms and busts of the mid-2000s were fueled by the rise and fall of structured finance that funded them. While other booms and busts in commercial real estate and the real house price boom of the late 1970s had preceded the twin real estate bubbles of the mid-2000s, those had not been funded on their upswings by securitization that later dried up. In contrast, the expansion of structured finance was the key driver of the twin real estate bubbles of the mid-2000s, which coincided with one another. The last decade's structured finance boom arose because the tranching in credit default obligations (CDOs) was made palatable to investors by derivatives enhancements made possible by the Commodity Futures Modernization Act (CFMA, see Roe 2011, Stout 2011) and because the easing of capital requirements on commercial mortgage-backed (CMBS) and private-label backed (PMBS) securities provided regulatory arbitrage incentives to fund an expansion of commercial real estate and nonprime residential lending via securitization. In both cases, the risk in the underlying real estate investments was underpriced in related-but slightly different ways-in commercial and residential real estate markets (Levitin et al. 2012).

Using survey data on CRE investors, appraisers, and deal makers, Duca \& Ling (2015) found that the risk premium in investors' required rate of return on CRE properties was mainly driven in the short and long run by the combination of a general risk premium (the Baa-10 year Treasury yield spread) and the effective or marginal capital requirement on CRE loans. The latter-which affects the liquidity of CRE-reflects the lessor of capital requirements on CRE loans or CMBS held in bank portfolios and the risk retention for banks that securitize CRE loans. Duca and Ling attribute the compression of cap rates (akin to a high price-to-earnings ratio) of the mid-2000s to a decline in the risk premium embedded in investors' required rate of return on CRE properties. Their empirical results indicate that the compression of risk premiums owed to both a reduction in effective capital requirements (the adoption of a $20 \%$ risk weight on high-rated CMBS-see Blundell-Wignall et al. 2008) and a narrowing of the corporate bond spread (which has a slightly less than one-for-one impact on the long-run risk premium). The former could be seen as an underpricing of CRE risk by capital regulation. The latter can be interpreted as an underpricing of CRE risk by investors insofar as they treat the risk on CRE as akin to that of Baa-corporate bonds that generally are more liquid than commercial properties. In other words, the implicit use of Baa yields as a benchmark for a required rate of return may be appropriate for some assets whose returns are based more off value-added (corporate profits or cash flows) than for CRE whose returns stem from rents and capital gains on land. Levitin \& Wachter (2012) show the trajectory of this underpricing of risk, with risk premia tightening during the boom.

For PMBS-the main funding source for subprime and Alt-A mortgages-the mispricing of risk owed to an underassessment of risk that likely reflected a lack of stress testing nonprime 
mortgages through both business and housing cycles. As Duca et al. (2010) show, while the limited history of the subprime mortgage delinquency rates before 2007 could be largely tracked by job growth, this obscured a key role played by house price appreciation. In the early phases of a financial liberalization, increased credit availability boosts housing demand (see Acolin et al. 2016, Pavlov \& Wachter 2011) and bids up real estate prices. Such gains can delay the appearance of loan defaults because troubled borrowers could pay off mortgages by selling or refinancing an appreciated property or continue making loan payments with funds from home equity loans. This is an acute problem in real estate markets because an underpricing of default risk in lending-which took the form of low teaser interest rates and excessively easy credit standards on nonprime mortgages-ultimately leads to inflated asset prices in markets of fixed supply, as stressed by Pavlov \& Wachter (2006, 2009). In addition, at times rising house prices can paradoxically increase the effective demand for housing because if expected appreciation is based on extrapolating recent prices (as is observed empirically-see Case et al. 2012), higher prices can raise expected appreciation and lower the perceived real user cost of housing, thereby fueling further increases in house prices and obscuring underlying loan quality problems. Moreover, even with the recognition that lax lending terms and underpriced put options were behind an unsustainable rise in housing prices, selling homes to take advantage of likely future price depreciation is not feasible (Wachter 2016, Levitin et al. 2012).

Only after the budget constraint effects of higher prices predominated did house prices level off in $2006^{2}$ and new subprime borrowers were no longer simply bailed out by price appreciation (Barakova et al. 2014). Shortly thereafter, subprime delinquencies mounted, inducing investors to flee nonprime MBS, which induced a reversal of the earlier easing of mortgage credit standards, setting off a house price bust (Duca et al. 2016). Similar interplay between price and default dynamics could also delay the appearance of loan quality problems in CRE and mask the underpricing of risk during the boom phases of real estate bubbles.

In addition, the underpricing of risk was transmitted to the pricing of residential and commercial real estate through somewhat different channels. In commercial real estate (CRE), the price bubble reflected the transmission of the mispricing of CRE by otherwise savvy investors through the earnings-multiples that they demanded, whereas the subprime boom reflected the transmission of underpriced mortgage interest rates as well as unsustainably easy mortgage credit standards although they both were fueled by regulatory shifts (McCoy et al. 2009).

\subsection{How and Why Real Estate Downturns Can Be Prolonged and Slow to Recover From}

There is an emerging consensus that deep and prolonged economic downturns are often linked to real estate busts both across countries and across time within the U.S. (inter alia, Bordo \& Haubrich 2012). This relationship between real estate bubbles and subsequent economic crashes has been observed across countries and over time, with the severity and frequency of

\footnotetext{
${ }^{2}$ Abraham \& Hendershott (1996) describe these dynamics as arising from the tension between the upward price momentum effect of appreciation through the real interest rates ("the bubble builder") versus the negative long-run tendency for house prices to fall back in line with their fundamentals ("the bubble burster"). The fall back to fundamentals can come quickly when price rises counter the impact of easing borrowing constraints on homeownership (Barakova et al. 2014) and price expectations reverse.
} 
this connection increasing since housing finance has been integrated into global capital markets (Green \& Wachter 2007). There are three underlying channels through which real estate cycles have recently had a pronounced role in downturns. In addition to traditional or conventional wealth effects of changes in gross housing wealth, these include changes in the ability to borrow against housing wealth, mortgage debt overhang effects, and damage to the financial system. These can be thought of as "real estate financial accelerators," akin to the more business-oriented financial accelerator of Bernanke et al. (1996). And each of these are negative externality effects that lenders do not internalize when making loan decisions, giving rise to more lending than is socially optimal (Turner 2015, Herring \& Wachter 1999).

In recent decades, homeowners have become more able to borrow against accumulated housing equity gains arising from house price appreciation or paying down mortgage principal. This phenomenon arose in the UK during the late 1980s and early 1990s-feeding a consumption boom when house prices rose and a consumption bust when house prices fell (Muellbauer \& Murphy 1997)-and has spread to other countries, such as Denmark (Browning et al. 2013), the U.S. (Hurst \& Stafford 2004, Green \& Wachter 2007) and Ireland. Micro evidence indicates that this is mainly a collateral effect, allowing otherwise credit-constrained households to borrow against housing collateral (inter alia, Hurst \& Stafford 2004). The effect operates through the cyclically changing availability of second liens; while LTVs appeared to be constant through the run-up to 2007, CLTVs (only knowable after the crisis since real time data were unavailable) increased dramatically (Levitin \& Wachter 2015). The time series evidence for the U.S. indicates that this ability to extract equity increased over the past several decades (e.g., Carroll et al. 2011), but fell back during and after the Great Recession (Duca et al. 2013). This up- and then down-swing in the liquidity of housing wealth amplified the positive and then negative effects of swings in gross housing assets of U.S. households, and for countries where home equity extraction is feasible (see Aron et al. 2012, for cross-country evidence).

An additional financial decelerator effect arises from the overhang of mortgage debt accumulated during housing booms that not only impairs housing activity, but also consumption (Mian $\&$ Sufi 2009, 2011). The latter arises because mortgage payment obligations depress consumption either directly by leaving less discretionary income or indirectly by inducing borrowers to be more cautious in consuming to reduce the risk of incurring future late payment penalties if the household lacks liquid assets. Collateral price declines exacerbate the latter effect by limiting the ability to refinance existing debt, which must then be repaid as opposed to refinanced. Empirical studies that disaggregate net worth into debt, gross housing assets, liquid financial assets, and illiquid or risky financial assets typically find a larger and similar-sized effect of debt and liquid financial assets on consumption than from the other components of net worth. Indeed, for the UK, U.S., and Australia, the marginal propensity to consume out of liquid assets minus debt is roughly five times the size of that of stock wealth and two to three times that of gross housing assets (see Aron et al. 2012, Duca et al. 2013). Both of these channels, one operating through the procyclicality of second lien access and the other through more general procyclicality of mortgage lending standards, affect residential mortgage lending.

The third channel through which a commercial or residential real estate bust has negative externality effects is through the damage it does to the financial system. By destroying bank 
capital and causing banks to fall short of capital requirements, the souring of loans extended during booms induces banks to tighten credit standards (Aron et al. 2012, Bordo et al. 2016) and curtail lending in general (inter alia, Bernanke \& Lown 1991, Kashyap \& Stein 2000, Peek \& Rosengren 1995). Indeed, real estate losses-particularly from commercial mortgages (inclusive of residential construction and land development loans) and CMBS holdings were even more tied to U.S. bank failures after the onset of the Great Recession than were home mortgages and PMBS holdings (Antoniades 2015). In addition to reducing financial intermediation, the uncertainty that real estate busts create about the net wealth of firms and their indirect exposures to counterparties and customers impairs the needed transparency of risk for financial markets to operate. The uncertainty about which firms had losses or indirect (e.g., counterparty risk or off-balance sheet exposures) led to thin trading in which increases in insolvency and liquidity risk reinforced one another, pushing down both asset prices and trading volumes (see Bernanke 2010) and pushing up corporate yield spreads. The resulting negative wealth, user cost of capital, and uncertainty effects of real estate busts on securities markets (direct finance) can thus be viewed as a third, general type of externality that individual lenders do not fully internalize and which can result in an above socially optimal build-up of real estate debt in booms. One implication of the special role played by real estate in financial and economic crises is that the rush to enact financial reform may have had unintended consequences of over-regulating types of lending that pose little systemic risk. For example, banks report making fewer small business loans for which the lack of hard information makes them subject to higher capital assessments in stress tests. Indeed, some measures show much higher bank regulatory burden (see Bordo et al. 2016, p. 26) and small business lending has grown slowly in the current U.S. economic recovery which has been characterized by unusually slow business formation.

\section{Progress in Addressing Macro-Prudential Real Estate Risks}

Since the financial crisis began, much has been done to detect and address macro-prudential risks in advanced countries, such as the implementation of Basel III at the national level in Europe and the implementation and rule-writing specific regulations for the Dodd-Frank Act in the U.S. The choice of early warning indicators of systemic risk and macro-prudential instruments across these countries reflect similarities and differences in mortgage funding models (see Wachter 2015, for a comparison between house price booms across these advanced economies). These can be classified as policies or tools aimed at (a) preventing financial excesses that result in crises and bolstering resiliency to the financial crises that do occur; and (b) addressing correlated risks that amplify the broad effects of financial crises. Some of the tools address more than one of these goals. In addition, each of these goals entails regulations or policies that are or could be imposed on lenders ("lender-based"), financial markets ("market-based"), and borrowers/investors ("borrower-based"), and which address the risks posed by innovations that either circumvent or make obsolete existing regulations, as well as risks posed by networks or interconnectedness. 


\subsection{Macro-Prudential Tools to Prevent and Limit Financial and Real Estate Crises}

Several major steps have been taken or are being implemented to prevent credit-booms that can fuel real estate bubbles. These include increased capital requirements and buffers for lenders, stress tests, limits on risk-taking in securities markets, limits on borrowers, and new liquidity requirements on banks and money market funds. Some of these steps also limit the intensity of crises. These include increases in regular and counter-cyclical buffer capital requirements and the adoption of forward-looking stress tests. In this regard, the counter-cyclical buffer is particularly useful in reducing the severity of credit crunches. In addition, the new liquidity requirements on banks and money funds would limit the intensity of runs and of fire sales when they occur.

\subsubsection{Increased Capital Requirements and Buffers for Lenders}

First, under Basel III capital requirements were raised on commercial banks in terms of overall and risk-based leverage ratios, along with the planned implementation of counter-cyclical capital buffers and additional capital requirements on large and globally systemically important institutions. ${ }^{3}$ The specific implementation of these lender-based restrictions has much commonality across Europe and the U.S., such as imposing an overall leverage ratio and tightening up the definition of bank equity capital. In particular, CRD IV in the EU applies generalized countercyclical capital buffer which is conditional on aggregate credit growth and which is also expected from all member states to limit regulatory arbitrage. Since January 2014, Switzerland-which is not under EU jurisdiction-has imposed a sector-specific counter-cyclical capital buffer (CCB) equal to $2 \%$ of risk-weighted positions secured by residential property.

Nevertheless, there are some differences in implementation. For example, in Europe, the counter-cyclical buffer and provisions requiring banks to build buffers are specified in terms of whether the credit-to-GDP ratio or gap exceeds a certain threshold chosen by individual member states. Some studies find that such thresholds have empirical evidence favoring their imposition (e.g., Borio 2014, Drehmann \& Juselius 2014, Drehmann \& Tsatsaronis 2014) or are effective in DSGE models (e.g., Alpanda et al. 2014) or in agent-based models (e.g., Popoyan et al. 2015). In contrast, the U.S. has not (to date) adopted thresholds for adjusting the counter-cyclical buffer based on an explicit credit-to-GDP ratio. One argument against using such ratios is that data revisions make them suboptimal on a real-time basis (Edge \& Meisenzahl 2011) and another is that credit outstanding tends to lag business and credit cycles.

Another difference across countries reflects the constrained latitude that Basel III provides countries with options to impose higher risk weights to some loan categories or capital surcharges on certain types of riskier loans. For example, in Ireland, Spain and the UK banks are required to hold additional capital if the share of real estate loans that have high LTVs or DSTIs exceeds certain thresholds, whereas higher risk weights or capital surcharges are levied on all high LTV or high DSTI mortgages in Belgium and Switzerland. Indirect sectoral capital requirements that

\footnotetext{
${ }^{3}$ In the 2000s large U.S. banks did not build up capital ratios as risks in the financial system rose. And while large U.S. banks built up capital during the 1920s as financial risks mounted in the absence of a large federal safety net, they needed liquidity and capital support in the Great Depression (see Koch et al. 2016).
} 
work on variables that affect capital requirements-such as risk weights (RWs) and loss given default (LGD) parameters-are more flexibly used under EU jurisdiction (since the countercyclical buffers are generalized and work only on aggregate credit side) due to their targeted nature. In particular, in Sweden and Norway regulatory authorities imposed a floor on RW calculated by banks on residential exposures to limit regulatory arbitrage opportunities if a bank uses the internal rating-based (IRB) model. Perhaps reflecting its pro-home-ownership or "American Dream" preferences, the U.S. has generally avoided imposing additional capital surcharges on riskier mortgages for purchasing existing homes. However, the U.S. did impose a 50 percent capital surcharge on construction and land development loans, partly given the historical tendency for default rates on these loans to rise more in real estate busts.

\subsubsection{Stress Tests}

Another major type of bubble-prevention tools aims at buttressing increased capital requirements with the imposition of stress tests on banks and systemically important nonbank financial firms. These tests limit incentives to make riskier loans within broad loan categories and prevent banks from delaying the write-off of bad loans as a means of complying with capital and safety requirements. Another advantage of stress tests is that the scenarios incorporated in them can be used to address forward-looking risks, tail risks, and correlated risks across lenders and the economy. And stress tests can address the unknown risks of financial innovations by levying extra capital buffers on the new and "untested" exposures they create. The implementation of stress tests differs by country, reflecting heterogeneity in the types of shocks or scenarios they may encounter, which encompasses different judgments about the probability of defaults and the rates of loss given default for different loans and borrowers operating in different goods or real estate markets. For example, except for annual EU-wide stress tests conducted by the European Banking Authority, Norway and Sweden augment their baseline scenarios in their national stress tests with adverse scenarios for mortgage and real estate markets. As a result, both countries have tightened the risk weights and default parameters applied to mortgages in their stress tests. ${ }^{4}$

From a broader perspective, the widespread adoption of stress tests can be interpreted as promulgating a lending culture of prudence, where the spirit of the law or regulations-not just the letter of the law-is followed. In a sense the prudential bank regulation approach of traditionally more prudent regulators (e.g., Canada and Australia) is now being applied more broadly, albeit perhaps in a form of more quantitative rather than qualitative judgment from the perspective of regulators. Nonetheless, the efficacy of stress tests will be limited if potentially large "shadow" providers of capital escape such tests while they remain in the shadow.

\subsubsection{Limits on Risk-Taking in Securities Markets}

In addition to adopting tougher capital requirements and stress tests, a third set of bubbleprevention measures entailed imposing market restrictions on risk-taking in securities markets. This has not been done so much in Europe, where there are more bank centric financial systems

\footnotetext{
${ }^{4}$ Norway tightened assessments of residential mortgage risk, imposing a LGD floor of 20\% since January 2014, while Sweden raised the risk weight floor on residential mortgages from $15 \%$ to $25 \%$ since November 2014 .
} 
and where efforts have been made to encourage an expanded role of securities markets in providing finance. Nevertheless, several EU member states have imposed LTV caps on mortgages eligible to be funded by covered bonds (see ESRB 2014). For example, Austria and Germany have a $60 \%$ LTV limit for residential and commercial mortgages, while Italy, Denmark and Spain have caps of $80 \%$ for residential and $60 \%$ for commercial mortgages. In Spain, there is a limit of $80 \%$, which can be relaxed to $95 \%$ if the remaining exposure of the issuing bank is covered by a guarantee from another bank. In the U.S., LTV caps have not been placed on RMBS, and more generally private label residential securitization is moribund with RMBS securitized by the GSEs, Fannie Mae and Freddie Mac, and or by Ginnie Mae for FHA and VA government guaranteed loans.

In Europe, there are some changes in appraisal rules that affect securitization. Prior to the crisis, the LTV on a home purchase mortgage could be based on the higher "appraised" property value rather than the actual transaction price, and LTVs were artificially depressed to make some mortgages eligible for being financed with covered bonds. Actual sales prices are now required to calculate LTVs in some countries (e.g., Spain), with national authorities having the option of imposing larger collateral haircuts to determine eligibility.

In the U.S. where more commercial as well as residential mortgage lending is funded in securities markets, a major step was taken to impose market-restrictions on risk-taking in securities markets. Specifically, to limit regulatory arbitrage, the DFA requires originators of CMBS and of private-label residential MBS that did not meet certain credit standards to retain a first loss position of 5 percent in such securities originated. This effectively imposes a 5 percent capital requirements on originators, thereby limiting-but not eliminating-regulatory arbitrage incentives of issuing CMBS and PMBS as a means of funding mortgages. Nevertheless, as Pavlov \& Wachter (2006) show, even with modest skin in the game, today's fees on mortgage lending will still be attractive if the "put option" is in the money and NPV of mortgage lending is expected to be negative.

Another step taken in the U.S. concerns new limits on which kinds of home mortgages can be securitized. Now such mortgages are limited to either government guaranteed mortgages (FHA and VA), mortgages meeting the underwriting criteria of Fannie Mae or Freddie Mac, or mortgages that have DSTI ratios below 43 percent with other restrictions on borrower attributes. However, this remains an open issue as the resolution of GSE reform is uncertain. The CMBS market has had a limited resurgence amid these requirements, although as noted, PMBS has not.

In straight-forward ways, the imposition of stress tests, new capital requirements, and risk retention rules reduce the risk that financial excesses will build up and thereby reduce the risk that financial crises occur. Nevertheless, there are several ways that market limits on risktaking could be further improved. One, in particular, involves the cost of securitization relative to holding loans on portfolio. The initial round of the DFA increased the capital requirements on loans held in bank portfolios by about 2.5 percentage points somewhat less than they increased the effective capital requirements by about 5 percentage points on securitizing assets through risk retention rules. This had the effect of directly improving the safety of banks while reducing some of the regulatory arbitrage incentives to circumvent bank capital requirements via securitization. 
However, there may be increased regulatory arbitrage via securitization unless the upcoming imposition of additional capital requirements in the form of counter-cyclical capital buffers and capital surcharges on SIFIs is matched by a further increase in the risk retention rules. As a result, any "direct" increase in the safety of banks from the phase-in of additional capital rules could be offset by increased securitization-especially in commercial real estate which is less subject to new regulations imposed on all originators than in the case of home mortgage lending and potentially in residential as well, if Fannie Mae and Freddie Mac are phased out. In addition, in the absence of a concomitant increase in risk retention rules, unless downpayment and debtservice requirements are imposed on nonconventional residential mortgages, the 5 percent risk retention rules may not adequately prevent a socially excessive level of nonprime mortgage origination funded, for example, by hedge funds which may not be treated as systemically important.

\subsubsection{Limits on Borrowers}

Another set of initiatives to limit the build-up of systemic risk involve direct restrictions on borrowers' ability to borrow (these differ from greater bank capital requirements on risky loans mentioned above). These have differed across countries, in part reflecting a lack of theoretical consensus about their efficacy. For example in DSGE models with endogenous distortions, reducing maximum limits on individual borrowing (e.g., lowering LTV caps) in periods of rapid credit growth or high debt-to-GDP ratios can improve financial stability (Brunnermeier \& Sannikov 2012, Rubio \& Carrasco-Gallego 2014, Lambertini et al. 2013). Other DSGE models point to the need for macro-prudential tools only with endogenous distortions; without such distortions, these models imply monetary policy should be used to quell credit bubbles rather than macro-prudential tools (e.g., Cecchetti \& Kohler 2012). In agent-based models, such restrictions promote both financial and macroeconomic stability (e.g., Popoyan et al. 2015).

The empirical evidence generally indicates a financial stability role for tools limiting or discouraging lending to high risk borrowers, but less about which specific tools are most efficacious. Cross-country studies generally find that limits on borrowers such as caps on LTVs, debt serviceto-income (DSTI) or debt-to-income (DTI) ratios are all effective in limiting large buildups in debt relative to income (e.g., Borio \& Shim 2007, Lim et al. 2011, Ciani et al. 2014, Dell'Ariccia et al. 2012). Kuttner \& Shim (2013), however, find evidence that limits on borrower debt service-to-income ratios tend to be more effective than LTV or DTI caps in stabilizing housing credit growth and house price appreciation. Interestingly, the U.S. has eschewed imposing LTV caps on mortgages not insured by federal agencies, in favor of shielding lenders from borrower lawsuits on mortgages meeting DSTI caps and other non LTV criteria.

In contrast to the U.S., Asian and European countries have been more open to imposing LTV caps across borrowers and to varying them counter-cyclically. For example, Hong Kong has imposed LTV caps, which it has adjusted to counter overvaluation in real estate. In the wake of the financial crisis, several European countries have imposed general LTV caps (e.g. Sweden, Belgium and the Netherlands) or more stringent ones on loans for high priced homes to first-time home-buyers or on investors ("buy-to-let"). While Canada does not have explicit LTV caps in general, its government insurer of mortgages has varied its LTV and DSTI limits 
on the mortgages it insures, while the regulatory authority reduced the maximum maturity of mortgages from 30 to 25 years to counter rising house price pressures from low interest rates (see Crawford 2015).

\subsubsection{New Liquidity Requirements on Banks and Money Market Funds}

A final set of actions to help prevent financial crises and limit their severity are several new liquidity requirements. The two most prominent of these are aimed at ensuring banks have sufficient liquidity to withstand stressful situations. One is the Liquidity Coverage Ratio (LCR), which requires banks to hold enough high quality liquid assets (HQLA) that could be sold to offset withdrawals of short-term funds over a 30-day period. The second is the net stable funding ratio (NSFR), which requires banks to have enough stable liabilities to fund assets over the next year under different stress scenarios. The above new liquidity requirements were generally applied and implemented similarly across the U.S. and European countries with some minor exceptions. ${ }^{5}$

However, reflecting the prevalence of floating net asset value (NAV) money market mutual funds in Europe and the former prevalence of fixed-NAV money funds in the U.S., several steps were taken in the U.S. (but not Europe) to improve the liquidity of money funds to limit the risk of runs and the fire sales of commercial paper. Most notable of these is the requirement that institutional money funds investing in non-Treasury paper use floating net asset values to price accounts. Earlier, U.S. money funds had a "don't break the buck" policy of not pricing money fund accounts below par when the assets the funds invested in fell in price. When large losses on commercial paper emerged around Lehman Brother's failure in September 2008, many account holders withdrew at par rather than risk capital losses if their fund failed. Investors in one major fund that did fail suffered capital losses, which though small in absolute size, were large relative to the narrow returns typically earned on short-run paper. This helps account for the $\frac{1}{2}$ trillion dollar run on U.S. institutional money funds in a three week period following Lehman's collapse.

The new liquidity requirements on banks and money funds reduce the risk of financial failure in three ways. First, they lower the risk of funding drying up on banks which could otherwise be tempted to excessively rely on uninsured funds and on institutional money funds whose prior "don't break the buck" account pricing could induce runs. This lowers the risk that a drying up of funding could induce a credit crunch at banks or a decline in the demand to hold commercial paper by money funds. Second, this lowers the risk of fire sales of private paper or bonds by banks and institutional money funds, which can feedback on asset prices and amplify a financial shock into a full blown financial crisis. ${ }^{6}$ Third, the liquidity requirements raise the financial system's costs of funding risky, longer duration assets with short-run debt that would otherwise have the externality effect of underpricing the tail risk of a financial crisis. In particular, investors in short-term debt may think that the risk they take is limited because they have the ability

\footnotetext{
${ }^{5}$ For example, new Congressional legislation mandates that U.S. municipal bonds be treated as high quality liquid assets despite the recent bankruptcies of Detroit and Puerto Rico.

${ }^{6}$ Duca $(2013 a, b)$ notes that the commercial paper market fully melted down in the Great Depression and that, thanks in part to federal interventions, a full meltdown-but not a partial meltdown-was avoided in the Great Recession.
} 
to sell such short-term debt should the risk of the debt issuer rise. However, in the event of a tail risk-such as a financial crisis where private paper in general becomes less liquid-there is little ability to limit risk by investing in short-term debt that rolls over rather than in long-term debt. As a result, the true funding cost of financing risk assets is underpriced because tail risk externalities are underpriced, thereby encouraging overinvestment in risky, illiquid assets such as real estate.

The new liquidity requirements help address all three effects by limiting the incentives of banks and money funds to use short-run funds to finance investments in longr duration risky assets ("carry trade" behaviour)-such as CMBS or PMBS-or to invest in the short-run debt of other financial institutions used to finance investments in risky assets. One issue is whether the new rules on money funds go far enough. A prime example is that retail money funds are not required to adopt floating NAV pricing, which not only continues posing a risk of runs on retail funds, but also encourages some institutional funds to convert to retail status by limiting the size of individual money fund accounts. While the latter action may not fully offset the rule, institutional investors can circumvent the floating NAV rules on institutional money by breaking their former large-sized accounts into many smaller-sized accounts. Such actions consequently limit the effectiveness of floating NAV pricing rules on institutional funds to reduce the risk of money fund runs.

\subsubsection{Market-Based Backstop Facilities}

Another set of macro-prudential tools that reduce the intensity of crises and aide recovery from them are the market-based backstop facilities created by the Federal Reserve and Treasury, referred to as lender-of-last-resort or credit-easing tools. Although these tools may be seen as preserving the functionality of particular markets, there are sizable macroeconomic externalities from possible market dysfunctionality that impart a macro-prudential dimension to these tools.

In response to the financial crisis, there was concern that Federal Reserve support of particular institutions under earlier "13-3(c)" powers encouraged too much moral hazard by large institutions. DFA circumscribes lender of last resort actions insofar as the central bank can set up backstop facilities for a broad array of market participants to use with the approval of the U.S. Treasury provided that such facilities are not designed to save any one or handful of institutions. During the financial crisis of 2007-09, five major actions (among more that space prescribes mentioning) were taken by the Fed to backstop markets which continue to be options allowed under DFA. One such facility was the Asset-Backed Commercial Paper Money Market Mutual Fund Liquidity Facility AMLF, under which the Federal Reserve made nonrecourse loans to money funds investing in private commercial paper. This too had the effect of cushioning the negative impact of the financial and money market crisis on commercial paper issuance (see Duygan-Bump et al. 2013). Another facility was the Commercial Paper Funding Facility $(\mathrm{CPFF})$, under which the Federal Reserve bought A1/P1 rated commercial paper at interest rates that were 100 basis points above the option-indexed swap rate. At one point, the Federal Reserve held about 20 percent of U.S. commercial paper outstanding and its actions prevented commercial paper from collapsing as much as it did during the Great Depression (Duca 2013a). Both of these actions were augmented by the U.S. Treasury's action to extend deposit insurance 
to money fund accounts and to insure many large time deposits issued by banks.

In addition to buttressing commercial paper and money funds, the Federal Reserve created three other noteworthy facilities (among many) to prevent liquidity problems from worsening the crisis. These included creating the Term Auction Facility (TAF) to provide banks with longer term discount loans and through a new facility with less stigma, the primary dealer facility to provide liquidity backstop to dealers who make markets in initially offered debt and equity, and creating facilities to fund eligible consumer, small business, and high-grade CMBS. Of these, the TAF helped make banks more liquid, allowing them to continue lending to and servicing real estate markets, while the last facility helped the top quality portion of the secondary CMBS market to continue operating-setting the stage for the later reemergence of limited CMBS issuance.

\subsection{Tools to Address Risks Posed by Network Externalities}

Aside from the macroeconomic effects that crises create by directly impairing lenders and the functioning of securities markets, ${ }^{7}$ there are important network risks that macro-prudential tools should address. For real estate assets whose collateral role can obscure tail risk, it is critical to monitor lending from all sources that might unsustainably elevate collateral prices. LTV caps and tougher capital requirements are ineffective if values are elevated by other sources of capital.

A prominent remaining correlated risk concerns the impact on consumption of mortgage equity withdrawals, which tend to boost consumption in liberalized economies during booms and restrain it when debt overhang effects prevail in their aftermath (see Aron et al. 2012, Muellbauer \& Murphy 1997). Most of the active mortgage equity withdrawal during the subprime housing boom took the form of cash-out mortgage refinancing or borrowing via home equity lines of credit. Starting in late 2007, the incidence of the former has been curtailed by Fannie Mae and Freddie Mac, which have imposed sizable surcharge fees withdrawing equity when refinancing mortgages. And new regulatory and enforcement scrutiny by the Consumer Finance Protection Bureau (CFPB) coupled with stress tests by other bank regulators have likely deterred riskier forms of mortgage equity withdrawal.

More generally, unless new econometric techniques are employed (Duca et al. 2013, being an exception), it is difficult to track how much the liquidity of housing wealth has been affected by new regulatory actions, thereby limiting the impact of house prices on consumer spending. Furthermore and moreover, without an explicit macro-prudential goal of limiting mortgage equity withdrawal effects, there is no guarantee that the new cash-out surcharges by Fannie Mae and Freddie Mac will continue or might be offset by more liberal policies by private MBS securitizers or by banks holding home equity loans in portfolio. Unlike other assets, holders of first liens are not required to be notified or give their permission for granting second liens; in part due to this, the capacity to track property level combined loan-to-value ratios (CLTVs) is limited (Levitin \& Wachter 2015). Thus, this important source of risk remains. Indeed, as documented by Kumar (2015), the 80 percent cap that Texas imposed on CLTVs for loans extracting home equity significantly limited the rise of home equity mortgage delinquencies compared to that of

\footnotetext{
${ }^{7}$ These include credit crunches, higher debt costs, and stock or bond wealth effects on consumer spending and on the ability of firms and consumers to raise funding.
} 
other U.S. states during the recent housing bust.

Other correlated risks concern how problems in one market can cascade into others, particularly if there are complex interactions and exposures. Aside from the fire sale issue, derivatives pose serious network risk exposures as was revealed in the financial crisis when CDS contracts suddenly became suspect as the contracts were not transparent and uniform, creating uncertainty about the exposures of private firms and impairing securities markets in general (Bernanke 2008). Reforms to address this include creating industry standards and a clearinghouse for many derivatives contracts, spurred in part by the experience in 2008 surrounding the real estate exposures of Bear Stearns and Lehman. ${ }^{8}$ Nevertheless, there are concerns that these may be insufficient to adequately prevent crises, such as that of 2008 (Duffie \& Zhu 2011).

Another macro-prudential tool for gauging both network effects and markets where imbalances are building are heat or radar maps designed to summarize and provide an overview of risks in the financial system-the development of which was recommended by Geanakoplos (2009, 2010). One example is the "heat map" of Aikman et al. (2015), which highlights that CRE valuations are a major outlying risk, consistent with the cap rate analysis of Duca \& Ling (2015). Another type maps out networks such as that of Gai et al. (2011).

Nevertheless, these are tools for identifying systemic risks, not necessarily for preventing or addressing them, which requires additional action. The development of such tools has enabled regulators to identify and act upon areas of risk, such as commercial real estate as noted by Federal Reserve Chair Yellen and the Board of Governors of the Federal Reserve System (2015).

One particular issue for such tools is the danger of rapid growth in new products not on regulators' radar maps. A poignant example is how in the lead up to the subprime crisis, the only widely available measures of residential loan-to-value ratios were based on conventional loans and for all home-buyers and indicated no problem, whereas gauges on LTVs for firsttime homebuyers who had access to nonprime mortgages showed a sharp deterioration in credit standards (Duca et al. 2011). More broadly, radar or heat maps will need to be capable of tracking a rapid expansion of less-regulated financial sectors (Wachter 2016).

Indeed, the empirical evidence indicates that the shadow banking system's provision of shortterm business credit (Duca 2016) and of commercial real estate finance (Levitin \& Wachter 2013, Duca \& Ling 2015) is prone to expanding rapidly when general risk aversion recedes or when regulatory arbitrage increases because of either financial innovation or regulatory laxity. And since shadow or security market financed lending depends on uninsured funding, these credit sources have been very vulnerable to runs and credit crunches during periods of distress. Owing to the volatility and potential size of shadow funding, the thin-trading of real estate and the lagging adjustment of construction, swings in shadow bank funding of real estate can induce real estate cycles that can undermine financial and macroeconomic stability even if banks are well-regulated. For this reason, tightening regulations on banks needs to be matched by tougher regulations on other sources of funding (such as toughening risk retention requirements on loan

\footnotetext{
${ }^{8}$ As Duffie \& Zhu (2011) note, "Effective clearing mitigates systemic risk by lowering the likelihood that defaults propagate from counterparty to counterparty. Clearing could also reduce the degree to which the solvency problems of a market participant are suddenly compounded by a flight of its OTC derivative counterparties such as when the solvency of Bear Stearns and Lehman Brothers was in question. Central clearing reduces the risk of disruptions to financial markets through fire sales of derivatives positions or of collateral held against derivatives positions."
} 
securitizers) to address the externalities those sources pose. ${ }^{9}$

\section{Concluding Comments}

From a broad macro-financial structure perspective, an underpricing of risk made possible by regulatory flaws contributed greatly to the housing and financial crises of the late-2000s in several advanced economies. In the U.S. such shortcomings enabled regulatory arbitrage and shadow financing to fuel the credit and twin real estate bubbles of the mid-2000s that led to the Great Recession. Insufficient macro-prudential policy also contributed to large real estate booms and busts in Ireland and Spain, whose economies were among the hardest hit in Europe before the sovereign debt crisis began in the spring of 2010. The effects of regulatory failure and mispricing of risk were most acute in real estate markets reflecting not only the relatively inelastic supply of land and thin trading of real estate, but also the amplification of shocks via backward-looking price expectations and the funding of consumption off distorted and elevated prices. The reversal of these excesses triggered downturns amplified by correlated shocks to financial intermediation and-in the cases of the U.S. and Ireland-to consumption. The resulting debt and residential real estate overhangs both deepened the Great Recession and prolonged the subsequent sluggish recovery from all three of these countries.

On the surface, this pattern of macroeconomic and financial behavior lends itself to interpreting the Great Recession as the outcome of a largely endogenous leverage or debt-super cycle. That interpretation, however, does not really account for the 80 year hiatus between the Great Depression and Great Recession in the U.S. Nor does it account for why twin booms and busts emerged in both commercial and residential real estate prices in the U.S. or for the rise and fall of structured finance and shadow banking that accompanied them during the past two decades.

More detailed analysis indicates that changes in regulation amplified financial innovation in the form of structured finance largely as part of the shadow bank system. This, in turn, spawned collateralized credit bubbles and fueled twin real estate bubbles and debt overhangs that ultimately crippled the U.S. financial system and its real economy. From this perspective, the leverage cycle of this century's first decade was not simply an endogenous development (e.g., Minsky 1982a,b). Rather regulatory actions undermined the restraining influence of capital requirements on credit creation, thereby spiking the proverbial punch bowl instead of taking it away. Hence better regulatory steps can help tame or temper the leverage cycle (Geanakoplos 2009, 2010).

The macro-prudential lessons from the Great Crisis highlight the need to prevent the buildup of excess real estate financing, limit the amplification and correlation of real estate risks, and enhance the ability to clean up real estate busts. More progress has been made in limiting the build-up of excess home purchase lending than in restricting excess price pressures in commercial

\footnotetext{
${ }^{9}$ For example, following the stock market crash of 1987, Federal Reserve was able to prevent a full-blown financial and economic crisis partly because the crash reflected an equity bubble that was not financed by debt and also because by providing liquidity to banks and indirectly to securities dealers, the Fed could stabilize a financial system in which only one-third of household and nonfinancial business debt was funded by securities markets. In contrast, the financial imbalances leading up to the Great Recession were debt-financed and about two-thirds of household and nonfinancial business debt was funded by securities markets when the subprime crisis hit. As a result, only regulating bank balance sheets and providing liquidity to just banks were inadequate to address the recent crisis.
} 
real estate. With respect to securities markets and the shadow bank system in the U.S., progress has also been made in reducing the risk of fire sale actions by banks and money funds than by other investors in CMBS. At a more concrete level, most of this has occurred by limiting debt-service burdens on households, implementing limited skin-in-the-game risk retention on parties creating mortgage-backed securities, instituting stress tests on banks and "systemically important financial institutions," and imposing liquidity limits on commercial banks and money funds.

There, however, remain major challenges. For one, some of the increased regulation of small business lending and community banks may have had the unintended consequence of stifling business formation and the economic recovery while doing little to address systemic risks that are more centered on real estate and high-leverage lending. Here, some well-targeted and narrow deregulatory steps may be warranted, but not a weakening of capital buffers or risk retention rules for securitization. Second, restricting the extent of home equity borrowing via loan-tovalue caps could limit the build-up of mortgage debt overhangs and their negative consequences as illustrated by recent experience in Texas (see Kumar 2015); even tracking the extent to which home equity lending is increasing a property's CLTV remains difficult (see Levitin \& Wachter 2015). Third, while general caps or Canadian-style limits on LTVs for home purchase mortgages could limit the risks posed by procyclical lending by shadow banks, the U.S. has so far decided not to impose general LTV limits unlike other countries (see Crowe et al. 2013). Instead, the U.S. has favored limits on debt service-to-income ratios, which international evidence may now favor (Kuttner \& Shim 2013). Fourth, the relatively less-increased regulation of lending to the commercial real estate sector relative to home real estate sector may help account for why recent CRE valuations are notably more elevated than house price valuations, induced in large part by low long-term real interest rates. Fifth, the Federal Reserve's recent announcement of higher capital requirements on systemically important financial institutions effectiveness in curbing real estate risks could be undermined by regulatory capital arbitrage unless there is a strengthening of "skin-in-the-game" risk retention rules for loss provisions on mortgage securitizers or of capital requirements on all holders of nonqualified mortgages. This may also be an issue for European nations that increase capital requirements on their systemically important institutions. Finally, there are uncertainties about the future structure of RMBS (e.g., GSE reform in the U.S.) and what entities would be responsible for (and hopefully effective in) maintaining underwriting standards. For these reasons, imposing macro-prudential limits on home equity borrowing could deter homeowners from stepping under debt-overhangs, while strengthening effective capital requirements and other regulations on securitized CRE and home mortgages could help keep real estate markets from reentering the shadows of structured finance.

\section{References}

Abraham, J. M. \& Hendershott, P. H. (1996), 'Bubbles in metropolitan housing markets', Journal of Housing Research 7, 191-207.

Acolin, A., Bricker, J., Calem, P. S. \& Wachter, S. M. (2016), 'Borrowing constraints and homeownership', American Economic Review 106, 625-29. 
Aikman, D., Kiley, M. T., Lee, S. J., Palumbo, M. \& Warusawitharana, M. (2015), 'Mapping heat in the U.S. financial system', Finance and Economics Discussion Series (2015-059).

Alpanda, S., Cateau, G. \& Meh, C. (2014), 'A policy model to analyze macroprudential regulations and monetary policy', BIS Working Paper (461).

Antoniades, A. (2015), 'Commercial bank failures during the great recession: the real (estate) story', ECB Working Paper (1779).

Aron, J., Duca, J. V., Muellbauer, J., Murata, K. \& Murphy, A. (2012), 'Credit, housing collateral, and consumption: evidence from Japan, the UK, and the U.S.', Review of Income and Wealth 58(3), 397423.

Barakova, I., Calem, P. S. \& Wachter, S. M. (2014), 'Borrowing constraints during the housing bubble', Journal of Housing Economics 24, 4-20.

Bernanke, B. (2010), 'Implications of the financial crisis for economics', speech to Conference Co-sponsored by the Center for Economic Policy Studies and the Bendheim Center for Finance, September 24(Princeton University).

Bernanke, B., Gertler, M. \& Gilchrist, S. (1996), 'The financial accelerator and the flight to quality', Review of Economics and Statistics 78, 1-15.

Bernanke, B. S. (2008), Financial regulation and financial stability, in 'Speech to the the Federal Deposit Insurance Corporations Forum on Mortgage Lending for Low and Moderate Income Households, Arlington, VA, July', Vol. 8.

Bernanke, B. S. \& Lown, C. S. (1991), 'The credit crunch', Brookings Papers on Economic Activity 1991(2), 205-247.

Blanchard, O., Dell'Ariccia, G. \& Mauro, P. (2010), 'Rethinking macroeconomic policy', Journal of Money, Credit and Banking 42(s1), 199-215.

Blundell-Wignall, A., Atkinson, P. et al. (2008), 'The subprime crisis: Causal distortions and regulatory reform', Lessons from the Financial Turmoil of 2007 and 2008 (Reserve Bank of Australia).

Board of Governors of the Federal Reserve System (2015), 'Monetary report to the congress', July .

Bordo, M. D., Duca, J. V. \& Koch, C. (2016), 'Economic policy uncertainty and the credit channel: Aggregate and bank level us evidence over several decades', NBER Working Paper (22021).

Bordo, M. D. \& Haubrich, J. G. (2012), 'Deep recessions, fast recoveries, and financial crises: Evidence from the american record', NBER Working Paper (18194).

Borio, C. (2014), 'The financial cycle and macroeconomics: What have we learnt?', Journal of Banking E) Finance 45, 182-198.

Borio, C. E. \& Shim, I. (2007), 'What can (macro-) prudential policy do to support monetary policy?', BIS Working Paper (242).

Browning, M., Gørtz, M. \& Leth-Petersen, S. (2013), 'Housing wealth and consumption: a micro panel study', The Economic Journal 123(568), 401-428.

Brunnermeier, M. K. \& Sannikov, Y. (2012), 'A macroeconomic model with a financial sector', American Economic Review 104(2), 379-421.

Carroll, C. D., Otsuka, M. \& Slacalek, J. (2011), 'How large are housing and financial wealth effects? a new approach', Journal of Money, Credit and Banking 43(1), 55-79.

Case, K. E., Shiller, R. J. \& Thompson, A. (2012), 'What have they been thinking? home buyer behavior in hot and cold markets', NBER Working Papers (18400).

Cecchetti, S. G. \& Kohler, M. (2012), 'When capital adequacy and interest rate policy are substitutes (and when they are not)', BIS Working Paper (379). 
Ciani, D., Cornacchia, W., Garofalo, P. et al. (2014), 'The macroprudential measures adopted in Europe for the real estate sector', Bank of Italy Occasional Papers (227).

Crawford, A. (2015), 'Building stable mortgage markets: Lessons from canada's experience', Journal of Money, Credit and Banking 47(S1), 81-86.

Crowe, C., Dell'Ariccia, G., Igan, D. \& Rabanal, P. (2013), 'How to deal with real estate booms: Lessons from country experiences', Journal of Financial Stability 9(3), 300-319.

Dell'Ariccia, G., Igan, D., Laeven, L. \& Tong, H. (2012), 'Policies for macrofinancial stability: How to deal with credit booms', IMF Staff Discussion Note (12/06).

Drehmann, M. \& Juselius, M. (2014), 'Evaluating early warning indicators of banking crises: Satisfying policy requirements', International Journal of Forecasting 30(3), 759-780.

Drehmann, M. \& Tsatsaronis, K. (2014), 'The credit-to-gdp gap and countercyclical capital buffers: questions and answers', BIS Quarterly Review, March.

Duca, J. V. (2013a), 'Did the commercial paper funding facility prevent a great depression style money market meltdown?', Journal of Financial Stability 9(4), 747-758.

Duca, J. V. (2013b), 'The money market meltdown of the great depression', Journal of Money, Credit and Banking 45(2-3), 493-504.

Duca, J. V. (2016), 'How capital regulation and other factors drive the role of shadow banking in funding short-term business credit', Journal of Banking 83 Finance 69(S1), S10-S24.

Duca, J. V. \& Ling, D. C. (2015), 'The other (commercial) real estate boom and bust: the effects of risk premia and regulatory capital arbitrage', manuscript .

Duca, J. V., Muellbauer, J. \& Murphy, A. (2010), 'Housing markets and the financial crisis of 2007-2009: lessons for the future', Journal of Financial Stability 6(4), 203-217.

Duca, J. V., Muellbauer, J. \& Murphy, A. (2011), 'House prices and credit constraints: Making sense of the US experience', The Economic Journal 121(552), 533-551.

Duca, J. V., Muellbauer, J. \& Murphy, A. (2013), 'How financial innovations and accelerators drive booms and busts in us consumption', Oxford University (mimeo).

Duca, J. V., Muellbauer, J. \& Murphy, A. (2016), 'How mortgage finance reform could affect housing', American Economic Review 106, 620-24.

Duffie, D. \& Zhu, H. (2011), 'Does a central clearing counterparty reduce counterparty risk?', Review of Asset Pricing Studies 1(1), 74-95.

Duygan-Bump, B., Parkinson, P., Rosengren, E., Suarez, G. A. \& Willen, P. (2013), 'How effective were the federal reserve emergency liquidity facilities? Evidence from the asset-backed commercial paper money market mutual fund liquidity facility', The Journal of Finance 68(2), 715-737.

Edge, R. M. \& Meisenzahl, R. R. (2011), 'The unreliability of credit-to-gdp ratio gaps in real-time: Implications for countercyclical capital buffers', International Journal of Central Banking 7(4), 261298.

ESRB (2014), 'The esrb handbook on operationalising macro-prudential policy in the banking sector', March .

Gai, P., Haldane, A. \& Kapadia, S. (2011), 'Complexity, concentration and contagion', Journal of Monetary Economics 58(5), 453-470.

Geanakoplos, J. (2009), The leverage cycle, in 'NBER Macroeconomics Annual 2009, Volume 24', University of Chicago Press, pp. 1-65.

Geanakoplos, J. (2010), 'Solving the present crisis and managing the leverage cycle', New York Federal Reserve Economic Policy Review 16(1), 101-131. 
Green, R. K. \& Wachter, S. M. (2007), 'The housing finance revolution', Proceedings-Economic Policy Symposium-Jackson Hole pp. 21-67.

Herring, R. J. \& Wachter, S. M. (1999), 'Real estate booms and banking busts: an international perspective', The Wharton School Research Paper (99-27).

Hurst, E. \& Stafford, F. (2004), 'Home is where the equity is: Mortgage refinancing and household consumption', Journal of Money, Credit and Banking 36(6), 985-1014.

Kashyap, A. K. \& Stein, J. C. (2000), 'What do a million observations on banks say about the transmission of monetary policy?', American Economic Review 90, 407-428.

Kelly, R., McCannb, F. \& OTooleb, C. (2015), 'Credit conditions, macroprudential policy and house prices', Central Bank of Ireland Research Technical Paper (06RT15).

Koch, C., Richardson, G. \& Van Horn, P. (2016), 'Bank leverage and regulatory regimes: Evidence from the great depression and great recession', The American Economic Review 106(5), 538-542.

Kumar, A. (2015), 'Do restrictions on home equity extraction contribute to lower mortgage defaults? evidence from a policy discontinuity at the Texas' border', Federal Reserve Bank of Dallas Working Paper (1410).

Kuttner, K. N. \& Shim, I. (2013), 'Can non-interest rate policies stabilize housing markets? evidence from a panel of 57 economies', NBER Working Paper (19723).

Lambertini, L., Mendicino, C. \& Punzi, M. T. (2013), 'Leaning against boom-bust cycles in credit and housing prices', Journal of Economic Dynamics and Control 37(8), 1500-1522.

Levitin, A. J., Pavlov, A. D. \& Wachter, S. M. (2012), 'Dodd-frank act and housing finance: Can it restore private risk capital to the securitization market, the', Yale Journal on Regulation 29, 155-180.

Levitin, A. J. \& Wachter, S. M. (2012), 'Explaining the housing bubble', Georgetown Law Journal 100(4), 1177-1258.

Levitin, A. J. \& Wachter, S. M. (2013), 'The commercial real estate bubble', Harvard Business Law Review (3), 83-118.

Levitin, A. J. \& Wachter, S. M. (2015), 'Second liens and the leverage option', Vanderbilt Law Review 68, 1243-1294.

Lim, C. H., Costa, A., Columba, F., Kongsamut, P., Otani, A., Saiyid, M., Wezel, T. \& Wu, X. (2011), 'Macroprudential policy: what instruments and how to use them? lessons from country experiences', IMF Working Paper (11/238).

McCoy, P. A., Pavlov, A. D. \& Wachter, S. M. (2009), 'Systemic risk through securitization: The result of deregulation and regulatory failure', Connecticut Law Review 41, 493-541.

Mian, A. \& Sufi, A. (2009), 'The consequences of mortgage credit expansion: Evidence from the US mortgage default crisis.', Quarterly Journal of Economics 124(4), 1449-1496.

Mian, A. \& Sufi, A. (2011), 'House prices, home equity-based borrowing, and the US household leverage crisis', The American Economic Review 101(5), 2132-2156.

Minsky, H. P. (1982a), 'Can it happen again? essay on instability and finance', New York: ME Sharpe .

Minsky, H. P. (1982b), 'The financial instability hypothesis: capitalist processes and the behavior of the economy, 1979', Financial crisis: theory, history and policy, Cambridge University Press 85 Maison des Sciences de lHomme pp. 13-39.

Muellbauer, J. \& Murphy, A. (1997), 'Booms and busts in the U.K. housing market', The Economic Journal 107(445), 1701-1727.

Pavlov, A. D. \& Wachter, S. M. (2009), 'Systemic risk and market institutions', Yale Journal on Regulation 26(2), 445-455. 
Pavlov, A. \& Wachter, S. (2011), 'Subprime lending and real estate prices', Real Estate Economics 39(1), $1-17$.

Pavlov, A. \& Wachter, S. M. (2006), 'The inevitability of marketwide underpricing of mortgage default risk', Real Estate Economics 34(4), 479-496.

Peek, J. \& Rosengren, E. (1995), 'The capital crunch: neither a borrower nor a lender be', Journal of Money, Credit and Banking 27(3), 625-638.

Popoyan, L., Napoletano, M. \& Roventini, A. (2015), 'Taming macroeconomic instability: Monetary and macro prudential policy interactions in an agent-based model', LEM Working Paper Series (2015/33).

Roe, M. J. (2011), 'The derivatives market's payment priorities as financial crisis accelerator', Stanford Law Review 63, 539.

Rubio, M. \& Carrasco-Gallego, J. A. (2014), 'Macroprudential and monetary policies: Implications for financial stability and welfare', Journal of Banking $\mathscr{E}$ Finance 49, 326-336.

Stout, L. A. (2011), 'Derivatives and the legal origin of the 2008 credit crisis', Harvard Business Law Review 1, 1-38.

Turner, A. (2015), Between Debt and the Devil: Money, Credit, and Fixing Global Finance, Princeton University Press.

Wachter, S. (2015), 'The housing and credit bubbles in the United States and Europe: A comparison', Journal of Money, Credit and Banking 47(S1), 37-42.

Wachter, S. M. (2016), Informed Securitization, University of Pennsylvania Press. 